\title{
PARAGENESIS OF PRIMARY MAGMATIC SR-BA-MG-CACARBONATES FROM ULTRA-FRESH HYPABYSSAL KIMBERLITE, LAC DE GRAS KIMBERLITE FIELD, SLAVE CRATON, NWT CANADA
}

\author{
John Armstrong ${ }^{1}$, Mark Wilson ${ }^{2}$, Robert Barnett ${ }^{3}$, Tom Nowicki ${ }^{4}$ and Bruce Kjarsgaard ${ }^{2}$, \\ ${ }^{I}$ C.S. Lord Northern Geoscience Centre, Canada; ${ }^{2}$ Geological Survey of Canada, Canada; ${ }^{3}$ R.L. Barnett Geological., \\ Canada, ${ }^{4}$ Mineral Services, Canada
}

\section{INTRODUCTION}

A suite of eight, ultra-fresh, Late Cretaceous to Eocene hypabyssal kimberlites were studied in order to better understand the petrogenesis of these bodies as a segment of a larger multi-disciplinary study of the Lac de Gras kimberlite field. The Leslie, Porpoise, Anaconda, Grizzly, Rat, Koala West, Misery East, and Rattler kimberlites examined are all located within the BHP-Billiton Ekati Mine claim block, central Slave Craton, approximately 360 kilometres northeast of Yellowknife.

This Group 1 kimberlite suite is distinguished by the preservation of primary textures and lack of alteration. Of particular interest is the chemistry of preserved primary subliquidus magmatic carbonate phases in these samples. Carbonates in Rattler, however, are different, and may be the products of high $\mathrm{T}$ fluids.

\section{GROUNDMASS MINERALOGY}

The hypabyssal kimberlites are characterized by fresh olivine macrocrysts, set in a groundmass of monticellite, carbonate, serpentine, apatite and spinel. Monitcellite, where present, occurs as 20-50micron anhedral grains which have co-precipitated with carbonate and phlogopite. Ekati monicellite grains are

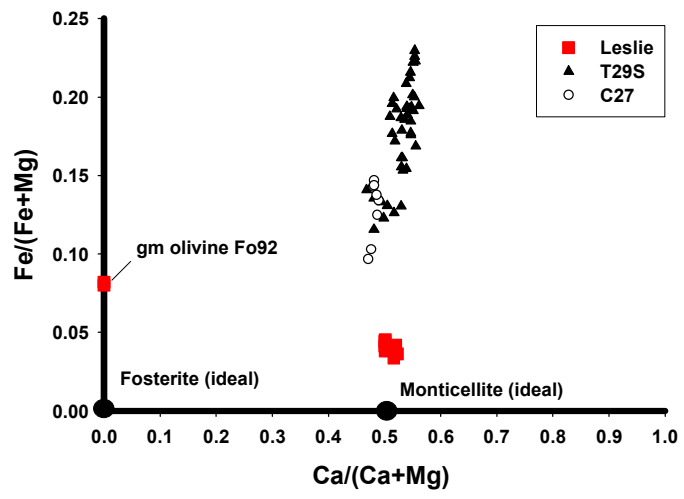

Figure 1. Compositional trends for Leslie monticellite (this study) and selected Diavik monticellite (Masun, 1999) distinguished from monticellite from hypabyssal material from the Diavik property (Masun, 1999) by high $\mathrm{xMg}$ (Figure1). Phenocrysts and microphenocryts (as small as $25 \mathrm{um}$ ) of olivine are fresh with minimal alteration.

Spinel occurs as 5-10 micron discrete disseminations associated with silicate rich portions of the kimberlite. Spinels are typically concentrically zoned and atoll-textures were not observed. Grains display core-rim zonation of decreasing $\mathrm{Cr} / \mathrm{Cr}+\mathrm{Al}$ at constant $\mathrm{xMg}$, consistent with Trend 1 spinels (Figure 2).

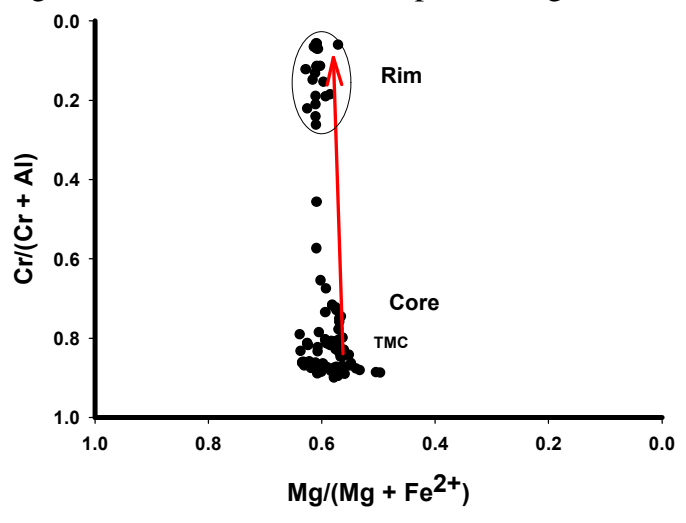

Figure 2. Compositional trends of spinel from Ekati sample suite

Phlogopite compositions for the suite examined fall within accepted fields for macrocryst, groundmass phenocrystic, and late stage barian-phlogopite, kinoshitalite. One kimberlite, Porpoise, demonstrates Trend 2 phlogopite evolutionary characteristics toward tetraferriphlogopite, but all other samples demonstrate typical kimberlite phlogopite Trend 1 and 3 zoning trends (zoning trends after Mitchell, 1986). Phlogopite with intermediate $\mathrm{BaO}$ compositions demonstrate high $\mathrm{Al}_{2} \mathrm{O}_{3}$ substitution and demonstrate linked substitutions with tetrahedral site $\mathrm{Al}$ and $\mathrm{Si}$. Serpentine is locally developed, but is not ubiquitous. 


\section{CARBONATE PARGENESIS}

\section{Introduction}

On the basis of morphology, paragenesis, chemistry and the criteria of Mitchell (1986 and references therein) three varieties of primary magmatic subliquidus carbonate are present. The first type are tabular to subhedral carbonate phenocrysts which have co-precipitated with olivine, apatite, spinel and minor serpentine. These features are interpreted as primary phenocryts (Figure 3a). 5-20 micron laths of $\mathrm{Sr}-\mathrm{Ba}$ calcite, reflecting an early microphenocryst phase (Figure 3b) are also observed in the groundmass and in autoliths. The second type of carbonates are found in irregular shaped to embayed $0.5-3 \mathrm{~mm}$ carbonate melt pockets (fig $3 \mathrm{a}$ ). These pockets contain randomly orientated 20 to 100 micron, tabular microphenocryts of Sr-Ba-calcite, which co-preciptated with anhedral monticellite and Ba-phlogopite/kinoshitalite. These calcite grains demonstrate elevated $\mathrm{Sr}$ (to $1.5 \mathrm{~mol} \% \mathrm{SrCO}_{3}$ and $1.05 \mathrm{~mol} \% \mathrm{BaCO}_{3}$; Table 1). The majority of the carbonate melt pockets have a relatively simple calcitic mineralogy, with a homogenous macroscopic appearance (fig 3c). In contrast, melt pockets in Rat and Rattler, contain more complex mineralogy, and have well preserved textural banding. A third variety of carbonate occurs in ovoid mm-scale domains consisting of microcrystalline calcitic carbonate, monticellite and phlogopite (e.g. in the Misery East kimberlite; Figure 3d).

\section{Carbonate phenocrysts and microphenocrysts}

Sharply bounded phenocrysts are comprised of large, polycrystalline grains of $\mathrm{Sr}-\mathrm{Ba}$ calcite (Figure 3e). Exsolved Sr-Ba-rich carbonates typically occur within low Sr-Ba domains. Fine (10-15 microns) grained microphenocryts and coarser grained carbonate phenocrysts associated with silicate-rich parts of the groundmass have compositions that mimic that of the carbonate in the melt pockets, for that particular sample. Carbonate phenocrysts and microphenocrysts may be partially replaced by serpentine.

\section{Carbonate Melt Pockets}

Magmatic Sr-Ba Calcite melt pockets
These are the predominant form of carbonate melt pocket observed for the different kimberlites studied. Calcites are typically zoned with early growth domains enriched in $\mathrm{Sr}$ and $\mathrm{Ba}$ (to $3 \mathrm{~mol} \% \mathrm{SrCO}_{3}$ and $1.92 \mathrm{~mol}_{2} \mathrm{BaCO}_{3}$; Table 1) with marginal zones trending toward end member calcite. The iron content of the carbonates is negligible. Within the melt pockets, euhedral calcite may appear to be anchored on silicate substrate (fig 3f,g), with sharp compositional boundaries, however for the most part, these $\mathrm{Sr}-\mathrm{Ba}$ calcite melt pockets are comprised of sub-anhedral interlocking masses.

\section{Mixed Calcite-Dolomite Segregations}

In the Rat and Rattler kimberlite, the melt pockets are quite different from those observed in other samples. Rhombs of sector- to oscillatory zoned inwardly projecting Sr-Ba-calcites are overgrown by anhedral calcite-dolomitess, sector zoned calcite-dolomite ${ }_{\mathrm{ss}}, 5$ micron to 20 micron anhedral magnestite, or by inwardly projecting sawtooth calcite-dolomite ${ }_{\mathrm{ss}}$ intergrowths (Figure 3h, i). Isolated 100 micron pockets between larger olivine macrocrysts are locally infilled by 5-10 micron banded, oscillatory, colloform-like, rhythmic mixed calcite-dolomite ${ }_{\text {ss }}$ (Figure 3j, k, 1). Intergrowths of magnestite with dolomite and intermediate calcite-dolomite solid solution indicate a primary origin for the magnesite, in equilibrium with other carbonate phases. Terminated $\mathrm{Sr}-\mathrm{Ba}$ calcite rhombs are rooted on silicate-rich domains, but do not necessarily coat the entire lining of the sharp walled segregation. Rhombs are enriched in $\mathrm{Sr}$ and $\mathrm{Ba}$ (to $1.7 \mathrm{~mol} \%$ $\mathrm{SrCO}_{3}$ and $1.67 \mathrm{~mol} \% \mathrm{BaCO}_{3}$; Table 1). Magnesite may form thin 3-5 micron overgrowths on the rhombs. Subsequent to $\mathrm{Sr}-\mathrm{Ba}$ calcite deposition oscillatory calcite, dolomite and intermediate calcitedolomite solid solution form homogenous anhedral intergrowths or rhomb parallel bands. These later carbonates characterised by moderate to low concentrations of $\mathrm{Sr}\left(<0.60 \mathrm{~mol} \% \mathrm{SrCO}_{3}\right)$ and $\mathrm{Ba}$.

\section{Quenched melt pools}

In the Misery East kimberlite, ovoid melt pockets contain essentially featureless aggregates of microcrystalline calcite (typically 1 - 10um size), with randomly distributed microcrystalline phlogopite and monticellite are observed. Based on textures, these are interpreted as extremely rapidly quenched melt pockets. 

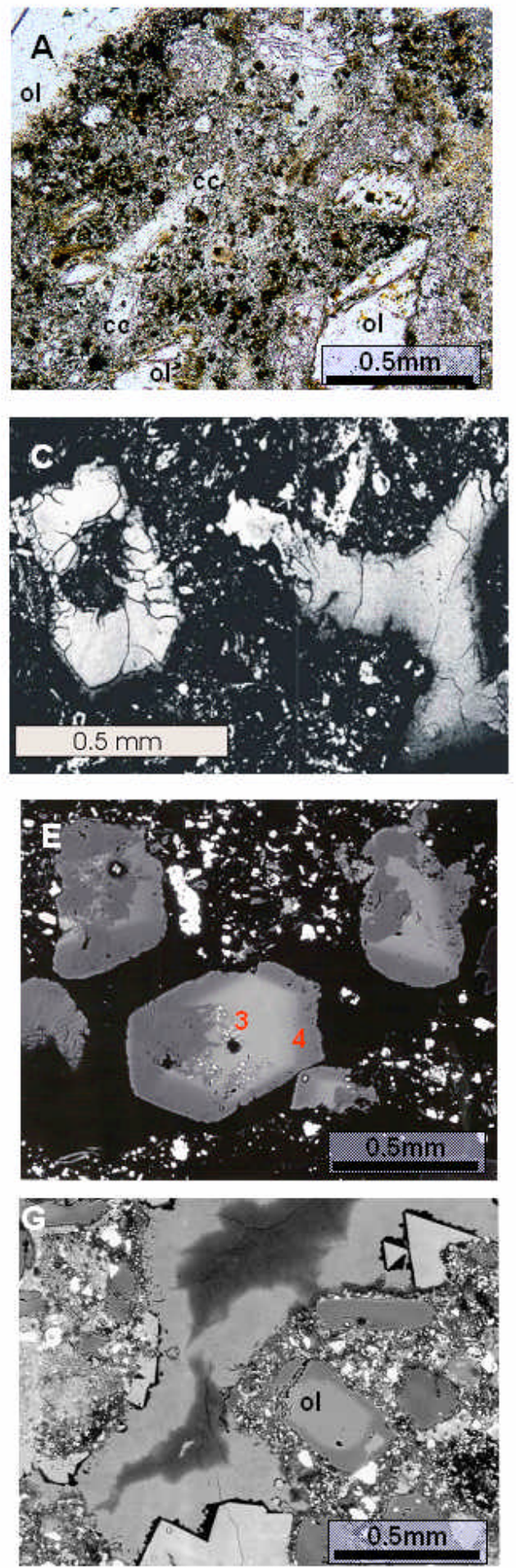
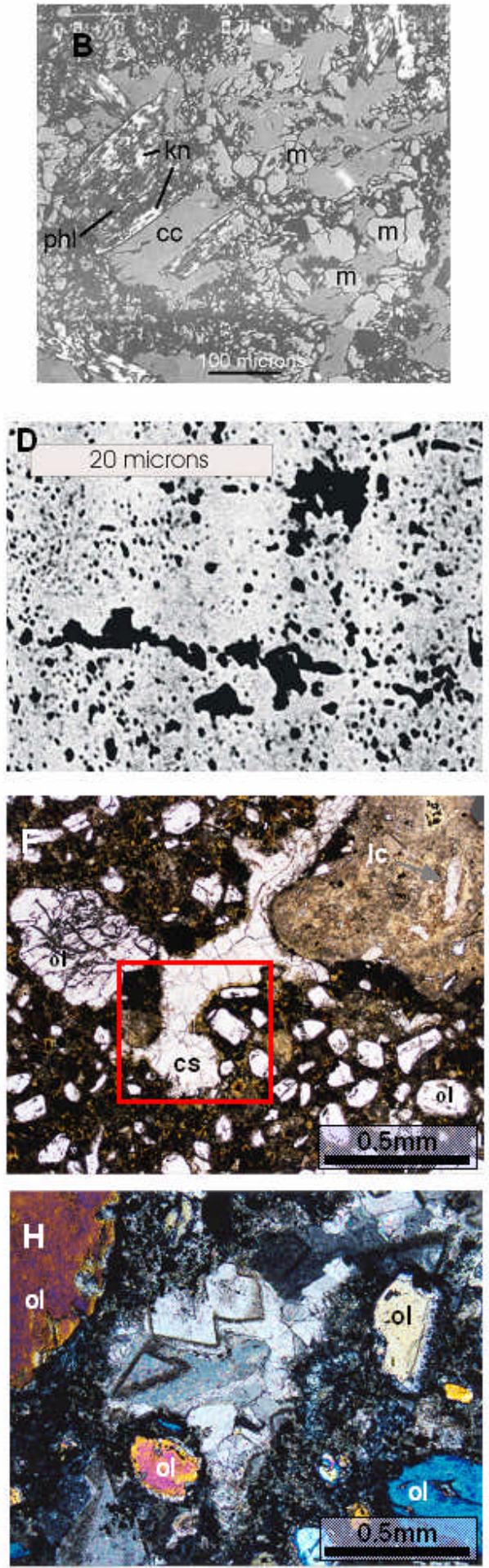

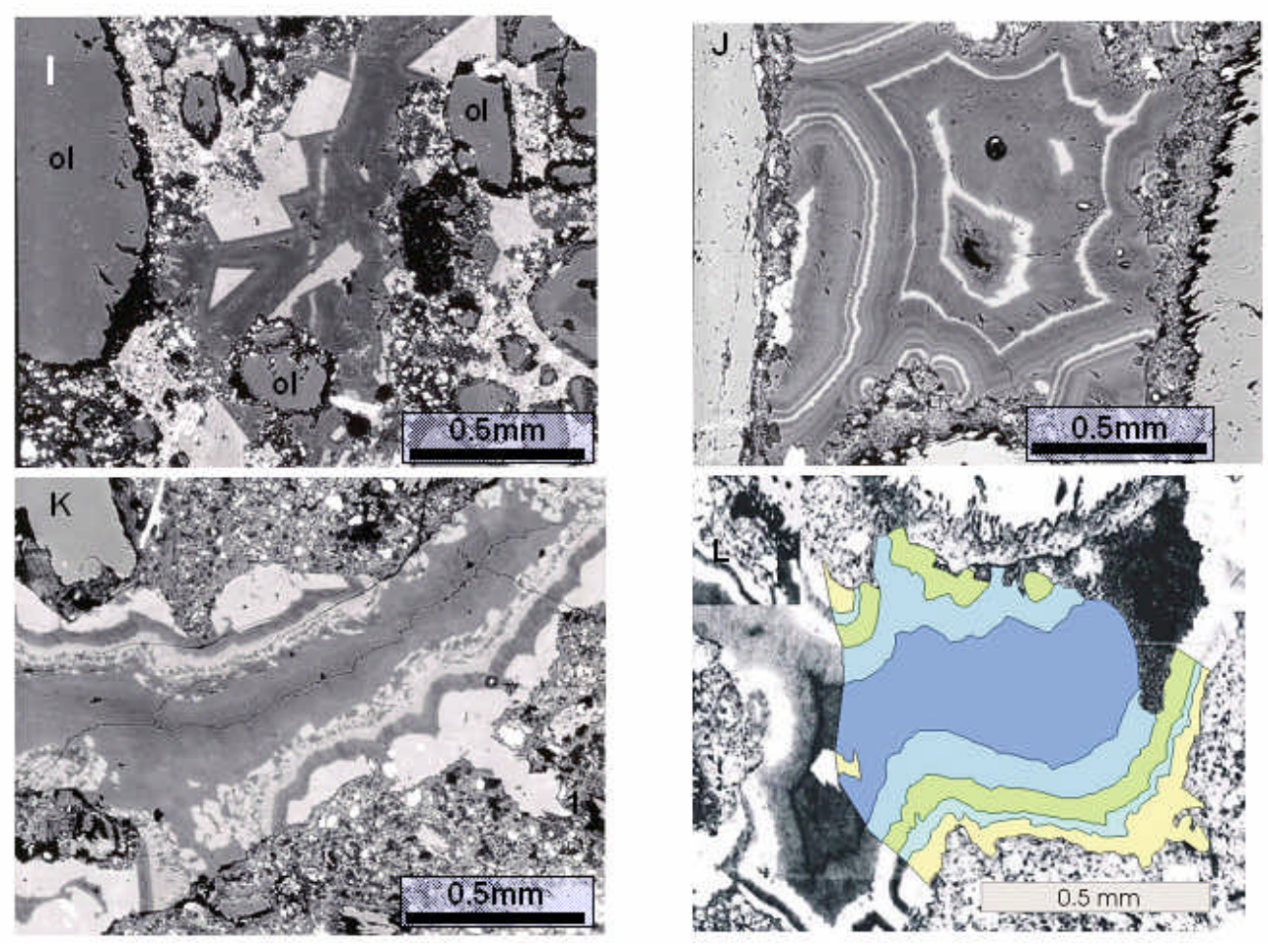

Figure 3. A) LDC09-28m, Leslie. Primary calcite phenocryst (cc) set in fine grained matrix of spinel, monticellite, olivine, and Olivine macrocrysts (ol); refer to analysis 1 Table 1 for calcite chemistry. B) LDC 09-28m. Leslie. Electron microprobe back scatter image of primary calcite phenocryst (cc) intergrown with anhedral monticellite (m) and phlogopite (phl)- kinshitolite (kn) intergrowths, refer to analysis 2 Table 1 for calcite chemistry . C) Back scatter electron image of subhedral carbonate phenocryst and an embayed, irregular-shaped, carbonate melt pocket. Probe analyses reveal both varieties of carbonate have the same range of compositions. Sample from the Misery East kimberlite, DDH-93-13-17.00 D) Back scatter electron image of a calcitic carbonate melt pocket at high magnification. Note the numerous black silicate inclusions of phlogopite and monticellite, in particular their commonly embayed texture suggesting the pocket represents quenched melt. Sample is from the Misery East kimberlite, DDH-93-13-17.00 E) DDH 92-02 306.75m (Grizzly) Electron microprobe back scatter image of Sr-Ba calcite segregation. Bright grey Sr-Ba calcite overgrown by calcite (rim domain) Analytical points 3,4 refer to analyses. 3,4 in Table 1 . F) DDH 94-08 2567.75m (Rat). Plane polarised light image of calcite - dolomite segregation. Cl refers to preserved calcite pheoncryst within autolith. Red box outlines field of view in 3G. 3G) Electron microprobe back scatter image of Sr-Ba calcite calcite-dolomite segregation. Rhombs of Sr-Ba calcite project inwards and are overgrown by later calcite-dolomite zones. $3 \mathrm{H}$ ) DDH96-17-Anaconda. Cross Nicols image of Sr-Ba calcite - calcite dolomite segregation. Note rhombs of Sr-Ba calcite projecting inward to centre of segregation. 3I) DDH96-17 Anaconda. Electron back scatter image of 3H, bright grey domains represent Sr-Ba calcite overgrown by sector zoned dolomite. 3J) DDH 96-13 (Rattler). Electron back scatter image of oscillatory zoned mixed calcite-dolomite growth within isolated segregation. Bright seed domains are $\mathrm{Sr}-\mathrm{Ba}$ calcite, oscillation in grey levels toward centre represent hyper solvus calcite-dolomite growth. 3K) DDH 96-13 (Rattler), vein like Sr-Ba calcite-dolomite segregation. Early rhombs of Sr-Ba calcite (bright grey) overgrown by later mixed calcite-dolomite. Note symmetrical inward growth patterns. 3L) Back scatter electron image of a texturally banded, carbonate melt pocket partially overlain by a digitized colour image representing the different types of carbonate present. The yellow area is calcite, the green is calcite-dolomite solid solution, and the three shades of blue represent different compositions of dolomite. Sample is from the Rattler kimberlite, DDH96-13-233.5

\section{DISCUSSION}

The Ekati kimberlites examined preserve primary calcite phenocrysts with elevated $\mathrm{Sr}$ and $\mathrm{Ba}$ compositions. These phenocrysts, along with Ba carbonates and apatite provide a sink for incompatible trace elements. Upon cooling and precipitation of silicates and oxides, the residual $\mathrm{Ca}$ $\mathrm{Mg}-\mathrm{Fe}-\mathrm{K}-\mathrm{Si}$-P-Ba-Sr melt becomes $\mathrm{CO}_{2}$-enriched. A variety of residual melt pockets form, with contrasting textures, consistent with varying quenching rates. In some instances, very rapid cooling generates melt pools of 10 micron scale quench aggregates (e.g. Misery east, fig 3d). Slower 
cooling produces broad anhedral masses of $\mathrm{Sr}-\mathrm{Ba}$ calcites followed by precipitation of purer forms of calcite (the dominant observed form of melt pool).

Development of certain textures within melt pools in Rattler indicates some carbonates may have precipitated from late stage carbothermal fluids. However, acicular crystals of hypersolvus calcitedolomite $_{\mathrm{ss}}$ within these pools is suggestive of precipitation from a melt. Initial calcites contain elevated Sr-Ba concentrations, followed by oscillatory growth of mixed calcite-dolomite inward toward the central portion of the segregation.

Elevated $\mathrm{Ba}$ and $\mathrm{Sr}$ concentrations within primary magmatic groundmass and melt pool carbonates enable temperature estimations based upon the phase relationships within the $\mathrm{BaCO}_{3}-\mathrm{CaCO}_{3}$ and $\mathrm{SrCO}_{3}$ $\mathrm{CaCO}_{3}$ systems (Chang, 1965). Temperature estimations range from $725 \mathrm{C}$ to $850 \mathrm{C}$. Within melt segregations carbonates with intermediate $\mathrm{CaCO} 3-$ $\mathrm{CaMg}\left(\mathrm{CO}_{3}\right)_{2}$ compositions are hypersolvus, indicating precipitation temperatures of $>750 \mathrm{C}<1000 \mathrm{C}$ utilizing the solvus geometry of Anovitz and Essene (1987).

Carbonate chemistry and temperatures of crystallisation indicate that the processes involved in their creation are linked to magmatic precipitation from melts, potentially followed in some cases by precipitation from carbonate-rich fluids. Textures vary with quenching rate with the rapidly quenching intrusion, and are not the result of later deuteric alteration
Table 1: Representative Carbonate Analyses

\begin{tabular}{|c|c|c|c|c|}
\hline & 1 & 2 & 3 & 4 \\
\hline $\mathrm{CaO}$ & 54.67 & 55.07 & 52.66 & 56.16 \\
\hline $\mathrm{FeO}$ & 0.12 & 0.01 & 0.00 & 0.09 \\
\hline $\mathrm{MgO}$ & 0.09 & 0.04 & 0.02 & 0.05 \\
\hline $\mathrm{MnO}$ & 0.00 & 0.00 & 0.05 & 0.11 \\
\hline SrO & 1.21 & 0.82 & 3.05 & 0.25 \\
\hline $\mathrm{BaO}$ & 1.61 & 1.09 & 2.59 & 0.00 \\
\hline Total & 57.70 & 57.03 & 58.70 & 56.66 \\
\hline $\mathrm{CaCO}_{3}$ & 97.40 & 98.39 & 95.15 & 99.37 \\
\hline $\mathrm{MgCO}_{3}$ & 0.22 & 0.01 & 0.05 & 0.12 \\
\hline $\mathrm{FeCO}_{3}$ & 0.17 & 0.00 & 0.00 & 0.12 \\
\hline $\mathrm{MnCO}_{3}$ & 0.00 & 0.00 & 0.07 & 0.15 \\
\hline $\mathrm{BaCO}_{3}$ & 1.05 & 0.72 & 1.72 & 0.00 \\
\hline $\mathrm{SrCO}_{3}$ & 1.17 & 0.80 & 3.00 & 0.23 \\
\hline \multirow[t]{2}{*}{ XMg } & 57 & 87 & 100 & 50 \\
\hline & 5 & 6 & 7 & 8 \\
\hline $\mathrm{CaO}$ & 54.01 & 55.13 & 47.92 & 33.43 \\
\hline $\mathrm{FeO}$ & 0.08 & 0.05 & 0.16 & 0.77 \\
\hline $\mathrm{MgO}$ & 0.71 & 0.54 & 8.44 & 18.46 \\
\hline $\mathrm{MnO}$ & 0.01 & 0.30 & 0.40 & 1.31 \\
\hline $\mathrm{SrO}$ & 1.00 & 0.87 & 0.08 & 0.12 \\
\hline $\mathrm{BaO}$ & 0.79 & 0.64 & 0.07 & 0.08 \\
\hline Total & 56.60 & 57.53 & 57.07 & 54.17 \\
\hline $\mathrm{CaCO}_{3}$ & 96.62 & 96.95 & 79.63 & 54.95 \\
\hline $\mathrm{MgCO}_{3}$ & 1.77 & 1.32 & 19.52 & 42.22 \\
\hline $\mathrm{FeCO}_{3}$ & 0.12 & 0.07 & 0.20 & 0.98 \\
\hline $\mathrm{MnCO}_{3}$ & 0.02 & 0.42 & 0.53 & 1.70 \\
\hline $\mathrm{BaCO}_{3}$ & 0.50 & 0.42 & 0.05 & 0.05 \\
\hline $\mathrm{SrCO}_{3}$ & 0.97 & 0.83 & 0.07 & 0.05 \\
\hline XMg & 94 & 95 & 99 & 98 \\
\hline
\end{tabular}

1-Leslie, phenocryst; 2-Leslie, cc intergrown with monticellite; 3-Grizzly, Sr-Ba calcite segregation core domain; 4-Grizzly, Sr-Ba calcite segregation rim to analyses 3; 5,6-Rat, Sr-Ba calcite rhomb ; 7-Rat, mixed calcite - dolomite solid solution overgrowth; 8-Rat, mixed calcite - dolomite solid solution overgrowth

\section{REFERENCES}

Anovitz, L.M., Essene, E.J., 1987. Phase equilibria in the system $\mathrm{CaCO}_{3}-\mathrm{MgCO}_{3}-\mathrm{FeCO}_{3}$. Journal of Petrology, $28,389-414$.

Chang, L.L.Y., 1965. Subsolidus phase relations in the system $\mathrm{BaCO}_{3}-\mathrm{SrCO}_{3}, \mathrm{SrCO}_{3}-\mathrm{CaCO}_{3}$, and $\mathrm{BaCO}_{3}-\mathrm{CaCO}_{3}$. Journal of Geology, 73, 346-368.

Masun, K.M., 1999. The petrology and mineralogy of the Lac de Gras kimberlite field, Slave Province, Northwest Territories: a comparative study. Unpublished MSc.thesis, Lakehead University, 324 pgs.

Mitchell, R.H., 1986. Kimberlites: Mineralogy, geochemistry, and petrology. Plenum Press, New York.

Contact: JP Armstrong, PO Box 1500 Yellowknife, NWT, Canada, X1A 2R3, E-mail: john_armstrong@gov.nt.ca 